\section{Prenatal care in Brazil}

\author{
Assistência pré-natal no Brasil
}

\author{
El cuidado prenatal en Brasil
}

1 Escola Nacional de Saúde Pública Sergio Arouca, Fundação Oswaldo Cruz, Brasil.

2 Instituto de Pesquisa Clinica Evandro Chagas, Fundação Oswaldo Cruz, Rio de Janeiro, Brasil. 3 Instituto Nacional de Saúde da Mulher, da Criança e do Adolescente Fernandes Figueira, Fundação Oswaldo Cruz, Rio de Janeiro, Brasil.

Correspondence E. F. Viellas

Departamento de Epidemiologia e Métodos Quantitativos em Saúde Escola Nacional de Saúde Pública Sergio Arouca, Fundação Oswaldo Cruz. Rua Leopoldo Bulhões 1.480, 8 o andar, Rio de Janeiro, $R J$ 21041-210, Brasil.

elaine.viellas@gmail.com

\begin{abstract}
This study aims to describe prenatal care provided to pregnant users of the public or private health services in Brazil, using survey data from Birth in Brazil, research conducted from 2011 to 2012. Data was obtained through interviews with postpartum women during hospitalization and information from hand-held prenatal notes. The results show high coverage of prenatal care (98.7\%), with $75.8 \%$ of women initiating prenatal care before 16 weeks of gestation and $73.1 \%$ having six or more number of appointments. Prenatal care was conducted mainly in primary health care units (89.6\%), public (74.6\%), by the same professional (88.4\%), mostly physicians (75.6\%), and 96\% received their hand-held prenatal notes. A quarter of women were considered at risk of complications. Of the total respondents, only $58.7 \%$ were advised about which maternity care service to give birth, and $16.2 \%$ reported searching more than one health service for admission in labour and birth. Challenges remain for improving the quality of prenatal care, with the provision of effective procedures for reducing unfavourable outcomes.
\end{abstract}

Prenatal Care; Maternal and Child Health; Maternal-Child Health Services
Elaine Fernandes Viellas 1 Rosa Maria Soares Madeira Domingues 2 Marcos Augusto Bastos Dias 3 Silvana Granado Nogueira da Gama 1 Mariza Miranda Theme Filha 1 Janaina Viana da Costa 1 Maria Helena Bastos 1 Maria do Carmo Leal 1

\section{Resumo}

O estudo tem por objetivo analisar a assistência pré-natal oferecida às gestantes usuárias de serviços de saúde públicos elou privados utilizando dados da pesquisa Nascer no Brasil, realizada em 2011 e 2012. As informações foram obtidas por meio de entrevista com a puérpera durante a internação hospitalar e dados do cartão de prénatal. Os resultados mostram cobertura elevada da assistência pré-natal (98,7\%) tendo 75,8\% das mulheres iniciado o pré-natal antes da $16^{a}$ semana gestacional e 73,1\% compareceram a seis ou mais consultas. O pré-natal foi realizado, sobretudo, em unidades básicas (89,6\%), públicas $(74,6 \%)$, pelo mesmo profissional $(88,4 \%)$, em sua maioria médicos (75,6\%), e 96\% receberam o cartão de pré-natal. Um quarto das gestantes foi considerado de risco. Do total das entrevistadas, apenas $58,7 \%$ foram orientadas sobre a maternidade de referência, e 16,2\% procuraram mais de um serviço para a admissão para o parto. Desafios persistem para a melhoria da qualidade dessa assistência, com a realização de procedimentos efetivos para a redução de desfechos desfavoráveis.

Cuidado Pré-Natal; Saúde Materno-Infantil; Serviços de Saúde Materno-Infantil 


\section{Introduction}

Prenatal care is an important component of health care for women during pregnancy. Practices routinely performed during this care are associated with better perinatal outcomes 1,2 . According to recommendations of the Ministry of Health 3, prenatal care should be through the incorporation of welcoming reception; development of educational and preventive actions without unnecessary interventions, early detection of diseases and identification of gestational risk; establishment of the link between prenatal care and place of birth, and easy access to quality health services from primary care to hospital care of high risk women.

National studies have demonstrated the existence of gaps in prenatal care, such as difficulties in access, late booking, inadequate number of prenatal visits and incomplete realization of the recommended procedures, affecting the quality and effectiveness of care 4,5,6. The lack of linkage between the services providing prenatal and delivery care is another problem identified, resulting in the pilgrimage of pregnant women in labour in search of a place for hospitalization, bringing additional health risks to the pregnant woman and her newborn 7,8 .

Nationwide data about prenatal care in Brazil is scarce. The information from the Information System on Live Births (SINASC) demonstrate an increase in prenatal coverage in the country, reaching values close to $100 \%$ in 2011 (Health Informatics Department. http://www.datasus. gov.br, accessed on 01/Jul/2013). However, this system only allows the analysis of the number of appointments conducted, and is restricted to pregnancies that resulted in a live birth. The System of Information of the Program for the Humanization of Prenatal and Birth Care - SispreNatal (http://sisprenatal.datasus.gov.br/SISPRENATAL/index.php), implemented in the year 2000 , allows access to other information, such as gestational age at onset of prenatal care, routine exams, anti-tetanus vaccination, number of prenatal visits and postpartum appointments. However, this data is not available for regular consultation and presents problems with underreporting ${ }^{9}$. The only study that evaluated prenatal care using data from this system for the entire country was conducted with pregnant women enrolled in the first two years of the program (2001 - 2002) when less than $30 \%$ of expectant mothers were enrolled 10 .

Specific studies, such as the Brazilian National Survey of Demographic and Health (PNDS), also provide data on prenatal care in the country. The most recent one, held in 200611 , found $80.9 \%$ prenatal care coverage, with six or more appointments, high performance of exams and provision of hand-held prenatal notes. However, this study is only based on interviews with women without checking the prenatal records, which is subject to more recall bias, because it includes pregnancies that occurred in the last five years.

Whereas it is important that national data allow a better assessment of the care provided, the objective of this study is to analyze the prenatal care provided to pregnant women in the public and/or private health services in Brazil, considering their suitability according to some predefined parameters of the Ministry of Health 12, their organization and relationship with other services of the health system as well as the profile of the users of prenatal services.

\section{Methodology}

Birth in Brazil is a Brazilian national, hospitalbased study of women who have recently given birth and their newborns, conducted from February 2011 to October 2012. The sample was selected in three stages. The first stage consisted of hospitals with 500 or more deliveries/year, stratified by the five geographical regions of the country, location (capital or non-capital), and type of hospital (private, public and mixed). The second stage was composed of days (minimum of seven days in a hospital) and the third stage by postpartum women. In each of the 266 hospitals sampled, 90 postpartum women were selected, totalling 23,940 participants interviewed. More information about the sample design is detailed in Vasconcellos et al. 13. In the first stage of the study face-to-face interviews were conducted with postpartum women during hospitalization and data was extracted from their medical records and of their newborn, and hand-held prenatal notes were photographed. Telephone interviews were conducted before six months and at twelve months after birth to collect data on maternal and neonatal outcomes. Detailed information on data collection is reported in do Carmo Leal et al. 14

While the main study is a cohort, this paper will present only the results of the first stage of the research, through a sectional cut.

To review the prenatal care, we investigated the coverage of this care (performing at least one prenatal appointment); reasons for not attending prenatal care, the proportion of women with early onset of prenatal care (up the 16th gestational week) and the reasons stated for this late start, number of prenatal care visits, the proportion of pregnant women with their hand-held 
prenatal notes upon admission for delivery and results of routine tests recorded (blood, urine and ultrasound scan), receiving information about delivery and the identification of signs of risk in pregnancy, and information about breastfeeding. For women who had their hand-held prenatal notes, we considered the gestational age at first prenatal care visit and the total number of registered appointments. For women who did not have their hand-held prenatal notes, we used the information obtained during the postpartum interview 15 .

We also verified the way of prenatal care is structured according to the source of payment (public or private), type of health care facility where women made most of their prenatal visits (primary care or hospital outpatient), professional cadre providing prenatal care in most visits (doctor or nurse) and continuity of provider (same professional throughout the prenatal care or not).

The integration of prenatal care services to other services in the health care network was measured by the proportion of pregnant women considered at risk referred to specialist services, the proportion of women informed about their place of hospitalization for childbirth, the proportion who were attended in these services, and the need to search for more than one service at the time of hospitalization for childbirth (i.e. Pilgrimage for childbirth).

Variables related to prenatal care were analyzed according to maternal characteristics: region of residence (North, Northeast, South, Southeast and Central), age (10-14 years $15-19$ years 20 -34 years 35 years and more), education (incomplete primary education, completed primary education, secondary education, higher education or more), race/ethnicity classified by self-reported colour of skin (white, black, brown, yellow, indigenous), marital status (living or not with partner), previous pregnancies $(0,1,2,3$ or more) and the occurrence of adverse outcomes in previous pregnancies (defined as the occurrence of at least one of the following conditions: stillbirth, neonatal deaths, preterm birth, low birth weight, hypertension and/or diabetes, 3 or more miscarriages).

Variables related to the planning of the current pregnancy and the satisfaction of women with this pregnancy were also used for the analysis of outcomes coverage of prenatal care, reasons for not attending prenatal care visits, early booking and reasons for late booking of prenatal care.

Not knowing that she was pregnant; personal problems (not wanting pregnancy, not knowing that prenatal care is important for health, financial hardship, hardship related to work/school, and lack of support to attend the service) and access barriers (difficulty for booking appointments, problems with health service and health professionals, and transportation difficulties) were the main categories used to explain the non-attendance to prenatal care and the late booking.

Data from hand-held prenatal notes and information received prenatally were analysed only according to the region of residence of the respondent.

The weighting of the data was calculated by the inverse of the probability of inclusion of each postpartum women in the sample. To ensure that the estimates were similar to the number of births in the population sampled in 2011, a calibration procedure was used in each selection stratum. Thus, the results presented are estimates for the population studied $(2,337,476$ births), based on the sample of 23,894 postpartum women interviewed.

An analysis for complex sampling to include design effects, given that cluster sampling was used, applying the chi-square statistical test with a significance level of 0.05 , to check for differences between proportions. The software used was SPSS version 17 (SPSS Inc., Chicago, USA).

This study was approved by the Ethics Committee for Research at Public Health National School, Oswaldo Cruz Foundation (ENSP/ Fiocruz), number 92/2010. Every effort has been adopted to ensure anonimity and confidentiality of information. Before the completion of each interview, consent was obtained after digital reading of the free and informed consent statement.

\section{Results}

Of the eligible postpartum women selected to participate in the study, $5.7 \%$ were not interviewed, and the major causes were refusal or early discharge, being replaced by others of the same unit, resulting in the interview 23,894 women.

The interviewed women had a mean age of 25.7 years, $18.2 \%$ were adolescents and $10.5 \%$ were women of 35 or more years of age. Most referred race/ethnicity of mixed-race (Brown skin colour), with yellow and indigenous representing a very small proportion of the total sample $(1.1 \%$ and $0.4 \%$, respectively). Half of the respondents had only primary education and $8.9 \%$ higher education. More than $80 \%$ reported living with a partner, $41.5 \%$ were in their first pregnancy and $15 \%$ had three or more previous pregnancies. For women who had been pregnant previously, approximately one third had negative outcomes in previous pregnancies. Less than half of the women said they planned their current pregnancy, 
$9.6 \%$ revealed they were dissatisfied when they learned they were pregnant and $2.3 \%$ reported having tried to interrupt the current pregnancy (Table 1)

The attendance of prenatal care in Brazil was $98.7 \%$, higher than $90 \%$ independent of maternal characteristics. Lowest coverage was observed in postpartum women living in the North region, indigenous women, less educated, unmarried and with higher number of previous pregnancies. Women with previous negative pregnancy outcomes did not want to get pregnant, were dissatisfied with their current pregnancy, and reported having tried to terminate the pregnancy also had lower coverage of prenatal care (Table 1).

Nationwide, $75.8 \%$ of women initiated prenatal care before the 16th gestational week and $73.1 \%$ had six minimum visits recommended by the Ministry of Health (Table 1).

The proportion of women with early initiation of prenatal care and with sufficient number of visits was similar to that observed for prenatal coverage: lower for residents in the North and Northeast, in women with less education, without a partner, with the largest number of previous pregnancies, who did not wish to become pregnant, dissatisfied with their current pregnancy and those who tried to interrupt their pregnancy. Women with previous negative outcomes in pregnancy initiated prenatal care later and had fewer visits than women who did not have these outcomes. Adolescents and women of black race/skin colour also showed a lower proportion of early initiation of prenatal care and lower number of prenatal care visits.

Access barriers and personal problems were the most frequent reasons for not attending prenatal care ( $43.2 \%$ and $40.6 \%$, respectively). Women living in the North and Northeast regions, and for women with less education the access barriers were predominant, while women without partners and those who tried to interrupt pregnancy reported more personal problems as reasons to not have attended prenatal care. Although not statistically significant, indigenous women presented three times higher proportion of access barriers than women of white race/colour (Table 2).

The difficulty for the diagnosis of pregnancy was the main reason cited for the late booking of prenatal care (46.6\%), followed by personal problems $(30.1 \%)$ and access barriers $(23.2 \%)$ (Table 3 ). The reasons for the late booking of prenatal care varied according to the characteristics of women. Access barriers were three times higher in indigenous women than for white women, and also three times higher for residents in the North compared to the South and Southeast regions.
There was also a gradient in the barriers to access by level of education and number of pregnancies, higher in women with lower education and greater number of pregnancies. Personal problems were reported more frequently by women without a partner, who did not want to get pregnant, dissatisfied with their current pregnancy or who tried to interrupt the pregnancy. High proportion of primigravidae stating the reason "did not know I was pregnant" initiated prenatal care later (Table 3).

Although more than $90 \%$ of women said receiving their hand-held prenatal notes during their prenatal care, only $72.1 \%$ had it in the hospital admission for delivery, with the lowest proportions observed in the North and Central. Over $80 \%$ of the analyzed hand-held prenatal notes had the first routine tests (blood glucose and urine), while the result of the second blood glucose test was only observed in $39.2 \%$ of cases. The North and Northeast had the lowest proportion of records of all the tests (Table 4).

Nationwide, $98.2 \%$ of the women reported having ultrasound exam in the prenatal period, with the smallest proportion observed in the North. The proportion of recording of the outcome in the prenatal notes was lower, and was available in $62.8 \%$ of hand held records tested, with a quarter of ultrasonography exams performed before the 14th gestational week. The largest proportions of recorded ultrasonography exams performed early in pregnancy were observed in the South and Southeast regions (Table 4).

In relation to the information received in prenatal care (Table 4), the guidance for breastfeeding and early detection of signs of risk in pregnancy were reported by more than $60 \%$ of the women, while guidance on beneficial practices for labour were cited by $41.1 \%$. Women living in the South and to a lesser extent, by residents in the North, most frequently mentioned receiving information about signs of early labour and risk signs. Information about beneficial practices for childbirth was more frequent in the Central region, with the Northeast region having the highest proportions of information on breastfeeding.

As to the source of service financing for prenatal care (Table 5), it was found that the majority of visits were made in the public health services and prenatal attendance was more frequent in these services for residents in the North and Northeast regions, women of lower age, lower education level, race/ethnicity of black skin colour or indigenous, living without a partner, with more pregnancies and previous negative pregnancy outcomes. 
Table 1

Proportional distribution of maternal characteristics according to the coverage of prenatal care, early booking and number of visits in a national sample of postpartum women. Brazil, 2011-2012 *.

\begin{tabular}{|c|c|c|c|c|c|c|c|c|c|}
\hline \multirow[t]{2}{*}{ Exposure/Outcome } & \multirow[t]{2}{*}{ Interviews } & \multirow{2}{*}{$\begin{array}{l}\text { Prenatal } \\
\text { care }\end{array}$} & \multirow[t]{2}{*}{$\mathrm{p}$-value } & \multirow{2}{*}{$\begin{array}{c}\text { Early } \\
\text { booking }\end{array}$} & \multirow[t]{2}{*}{$\mathrm{p}$-value } & \multicolumn{3}{|c|}{ Number of prenatal visits } & \multirow[t]{2}{*}{ p-value } \\
\hline & & & & & & $1-3$ & $4-5$ & $\geq 6$ & \\
\hline \multicolumn{10}{|l|}{ Region } \\
\hline North & 9.6 & 97.5 & & 64.4 & & 16.2 & 26.4 & 57.3 & \\
\hline Northeast & 28.9 & 98.5 & & 73.7 & & 11.3 & 23.2 & 65.6 & \\
\hline Southeast & 42.5 & 98.8 & & 78.5 & & 7.1 & 13.1 & 79.7 & \\
\hline South & 12.5 & 99.5 & & 78.8 & & 7.4 & 14.8 & 77.8 & \\
\hline Central & 6.5 & 98.7 & 0.006 & 78.0 & $<0.001$ & 6.3 & 17.3 & 76.4 & $<0.001$ \\
\hline \multicolumn{10}{|l|}{ Age (years) } \\
\hline 10-14 & 1.0 & 97.2 & & 51.7 & & 26.0 & 22.3 & 51.7 & \\
\hline $15-19$ & 18.2 & 98.5 & & 66.7 & & 13.5 & 24.1 & 62.4 & \\
\hline $20-34$ & 70.4 & 98.7 & & 77.5 & & 8.2 & 16.7 & 75.2 & \\
\hline 35 or more & 10.5 & 98.7 & 0.304 & 82.0 & $<0.001$ & 6.9 & 13.6 & 79.4 & $<0.001$ \\
\hline \multicolumn{10}{|l|}{ Race/Ethnicity/Skin colour } \\
\hline White & 33.8 & 99.2 & & 80.8 & & 7.3 & 12.9 & 79.8 & \\
\hline Black & 8.6 & 98.1 & & 69.2 & & 13.4 & 19.6 & 67.1 & \\
\hline Brown & 56.1 & 98.5 & & 73.8 & & 9.6 & 20.5 & 69.9 & \\
\hline Yellow (Asian) & 1.1 & 98.3 & & 76.6 & & 7.7 & 16.8 & 75.5 & \\
\hline Indigenous & 0.4 & 95.0 & 0.001 & 70.3 & $<0.001$ & 19.7 & 14.3 & 66.0 & $<0.001$ \\
\hline \multicolumn{10}{|l|}{ Mother's level of education } \\
\hline Incomplete Primary School & 26.6 & 96.9 & & 64.2 & & 16.4 & 26.2 & 57.4 & \\
\hline Complete Primary School & 25.6 & 98.8 & & 72.0 & & 9.5 & 20.5 & 70.0 & \\
\hline Complete Secondary School & 39.0 & 99.5 & & 82.3 & & 5.8 & 12.8 & 81.5 & \\
\hline University and further & 8.9 & 100.0 & $<0.001$ & 91.8 & $<0.001$ & 2.2 & 6.9 & 90.9 & $<0.001$ \\
\hline \multicolumn{10}{|l|}{ Conjugal status } \\
\hline Without partner & 18.6 & 96.9 & & 64.2 & & 15.4 & 21.0 & 63.5 & \\
\hline With partner & 81.4 & 99.1 & $<0.001$ & 78.4 & $<0.001$ & 7.8 & 17.0 & 75.2 & $<0.001$ \\
\hline \multicolumn{10}{|l|}{ Previous pregnancies } \\
\hline None & 41.5 & 99.4 & & 79.6 & & 7.0 & 16.0 & 77.0 & \\
\hline 1 & 28.0 & 98.9 & & 77.9 & & 8.7 & 16.1 & 75.2 & \\
\hline 2 & 15.5 & 99.0 & & 71.9 & & 11.0 & 19.3 & 69.7 & \\
\hline 3 or more & 15.0 & 95.9 & $<0.001$ & 64.9 & $<0.001$ & 14.3 & 24.4 & 61.3 & $<0.001$ \\
\hline \multicolumn{10}{|l|}{ Previous negative outcomes } \\
\hline No & 72.2 & 98.4 & & 74.0 & & 9.9 & 18.7 & 71.4 & \\
\hline Yes & 27.8 & 97.4 & 0.025 & 70.5 & 0.002 & 12.8 & 20.1 & 67.2 & 0.002 \\
\hline \multicolumn{10}{|l|}{ Wanted to get pregnant } \\
\hline Wanted to get pregnant & 44.6 & 99.5 & & 84.7 & & 5.6 & 13.7 & 80.7 & \\
\hline Wanted to wait longer & 25.5 & 98.9 & & 74.0 & & 8.6 & 19.3 & 72.1 & \\
\hline Did not want to get pregnant & 29.9 & 97.2 & $<0.001$ & 63.7 & $<0.001$ & 15.1 & 22.7 & 62.2 & $<0.001$ \\
\hline \multicolumn{10}{|l|}{ Feelings towards pregnancy } \\
\hline Satisfied & 69.4 & 99.2 & & 80.9 & & 6.8 & 15.3 & 77.9 & \\
\hline More or less satisfied & 21.0 & 97.8 & & 65.7 & & 12.5 & 24.0 & 63.5 & \\
\hline Dissatisfied & 9.6 & 96.6 & $<0.001$ & 60.2 & $<0.001$ & 19.2 & 22.0 & 58.9 & $<0.001$ \\
\hline \multicolumn{10}{|l|}{ Tried to terminate the pregnancy } \\
\hline No & 97.7 & 98.8 & & 76.3 & & 8.9 & 17.6 & 73.5 & \\
\hline Yes & 2.3 & 94.2 & $<0.001$ & 53.4 & $<0.001$ & 20.9 & 27.8 & 51.3 & $<0.001$ \\
\hline Total (national sample) & 100.0 & 98.7 & & 75.8 & & 9.2 & 17.8 & 73.1 & \\
\hline
\end{tabular}

* Values are weighted according to sample design. 
Table 2

Proportional distribution of mother's characteristics and the main reasons for no enrolment for prenatal care in a national sample of postpartum women in Brazil, 2011-2012 *.

\begin{tabular}{|c|c|c|c|c|}
\hline \multirow[t]{2}{*}{ Exposure/Outcome } & \multicolumn{3}{|c|}{ Main reasons for no enrolment for prenatal care } & \multirow[t]{2}{*}{ p-value } \\
\hline & $\begin{array}{c}\text { Did not know she was } \\
\text { pregnant }\end{array}$ & Personal problems & Access barrier & \\
\hline \multicolumn{5}{|l|}{ Region } \\
\hline North & 7.0 & 24.5 & 68.4 & \\
\hline Northeast & 15.3 & 29.3 & 55.4 & \\
\hline Southeast & 18.4 & 55.7 & 25.9 & \\
\hline South & 24.2 & 54.2 & 21.6 & \\
\hline Central & 25.5 & 38.6 & 35.9 & $<0.001$ \\
\hline \multicolumn{5}{|l|}{ Age (years) } \\
\hline $10-14$ & 20.3 & 20.5 & 59.2 & \\
\hline $15-19$ & 10.0 & 31.3 & 58.7 & \\
\hline $20-34$ & 17.2 & 44.7 & 38.1 & \\
\hline 35 or more & 20.5 & 34.9 & 44.5 & 0.293 \\
\hline \multicolumn{5}{|l|}{ Race/Ethnicity/Skin colour } \\
\hline White & 27.0 & 42.0 & 31.0 & \\
\hline Black & 14.5 & 30.9 & 54.6 & \\
\hline Brown & 14.0 & 42.0 & 44.0 & \\
\hline Yellow (Asian) & - & 77.9 & 22.1 & \\
\hline Indigenous & - & 14.5 & 85.5 & 0.317 \\
\hline \multicolumn{5}{|l|}{ Mother's level of education } \\
\hline Incomplete Primary School & 10.9 & 37.3 & 51.8 & \\
\hline Complete Primary School & 19.1 & 43.1 & 37.8 & \\
\hline Complete Secondary School & 33.6 & 50.2 & 16.2 & \\
\hline University and further & - & - & - & 0.009 \\
\hline \multicolumn{5}{|l|}{ Conjugal status } \\
\hline Without partner & 16.4 & 59.4 & 24.2 & \\
\hline With partner & 15.6 & 27.2 & 57.2 & $<0.001$ \\
\hline \multicolumn{5}{|l|}{ Number of previous pregnancies } \\
\hline None & 22.2 & 37.5 & 40.3 & \\
\hline 1 & 15.0 & 38.1 & 46.9 & \\
\hline 2 & 17.4 & 37.7 & 44.9 & \\
\hline 3 or more & 14.2 & 43.9 & 41.9 & 0.944 \\
\hline \multicolumn{5}{|l|}{ Previous negative outcomes } \\
\hline No & 9.5 & 42.4 & 48.2 & \\
\hline Yes & 23.5 & 39.5 & 36.9 & 0.118 \\
\hline \multicolumn{5}{|l|}{ Wanted to get pregnant } \\
\hline Wanted to get pregnant & 8.4 & 41.9 & 49.6 & \\
\hline Wanted to wait longer & 18.7 & 36.4 & 44.8 & \\
\hline Did not want to get pregnant & 16.7 & 42.3 & 41.0 & 0.686 \\
\hline \multicolumn{5}{|l|}{ Feelings towards pregnancy } \\
\hline Satisfied & 15.7 & 33.9 & 50.4 & \\
\hline More or less satisfied & 16.3 & 42.4 & 41.4 & \\
\hline Dissatisfied & 17.0 & 49.1 & 33.9 & 0.607 \\
\hline \multicolumn{5}{|l|}{ Tried to terminate the pregnancy } \\
\hline No & 17.8 & 37.4 & 44.8 & \\
\hline Yes & - & 73.3 & 26.7 & 0.004 \\
\hline Total (national sample) & 16.2 & 40.6 & 43.2 & \\
\hline
\end{tabular}

* Values are weighted according to sample design. 


\section{Table 3}

Proportional distribution of mothers' characteristics and the main reasons for late booking of the first prenatal visit in a national sample of postpartum women in Brazil, 2011-2012 *.

\begin{tabular}{|c|c|c|c|c|}
\hline \multirow[t]{2}{*}{ Exposure/Outcome } & \multicolumn{3}{|c|}{ Main reasons for late booking of the first prenatal visit } & \multirow[t]{2}{*}{ p-value } \\
\hline & $\begin{array}{c}\text { Did not know she was } \\
\text { pregnant }\end{array}$ & Personal problems & Access barrier & \\
\hline \multicolumn{5}{|l|}{ Region } \\
\hline North & 29.7 & 27.1 & 43.2 & \\
\hline Northeast & 43.6 & 32.6 & 23.7 & \\
\hline Southeast & 52.8 & 32,1 & 15.1 & \\
\hline South & 61.3 & 25.9 & 12.8 & \\
\hline Central & 49.5 & 24.5 & 26.0 & $<0.001$ \\
\hline \multicolumn{5}{|l|}{ Age (years) } \\
\hline $10-14$ & 36.0 & 44.7 & 19.3 & \\
\hline $15-19$ & 46.6 & 30.6 & 22.8 & \\
\hline $20-34$ & 46.2 & 29.9 & 23.9 & \\
\hline 35 or more & 54.7 & 25.2 & 20.0 & 0.497 \\
\hline \multicolumn{5}{|l|}{ Race/Ethnicity/Skin colour } \\
\hline White & 54.8 & 29.6 & 15.5 & \\
\hline Black & 41.2 & 35.6 & 23.2 & \\
\hline Brown & 44.3 & 29.6 & 26.1 & \\
\hline Yellow (Asian) & 43.9 & 14.6 & 41.5 & \\
\hline Indigenous & 35.9 & 18.0 & 46.1 & 0.003 \\
\hline \multicolumn{5}{|l|}{ Mother's level of education } \\
\hline Incomplete Primary School & 37.7 & 32.7 & 29.6 & \\
\hline Complete Primary School & 49.5 & 30.1 & 20.5 & \\
\hline Complete Secondary School & 60.8 & 25.5 & 13.7 & \\
\hline University and further & 75.9 & 15.6 & 8.4 & $<0.001$ \\
\hline \multicolumn{5}{|l|}{ Conjugal status } \\
\hline Without partner & 46.1 & 38.9 & 15.0 & \\
\hline With partner & 46.9 & 26.1 & 27.0 & $<0.001$ \\
\hline \multicolumn{5}{|l|}{ Previous pregnancies } \\
\hline None & 53.4 & 27.2 & 19.4 & \\
\hline 1 & 51.1 & 26.3 & 22.5 & \\
\hline 2 & 43.4 & 33.2 & 23.4 & \\
\hline 3 or more & 35.7 & 35.5 & 28.8 & 0.002 \\
\hline \multicolumn{5}{|l|}{ Previous negative outcomes } \\
\hline No & 41.7 & 34.3 & 24.0 & \\
\hline Yes & 47.7 & 24.8 & 27.5 & 0.021 \\
\hline \multicolumn{5}{|l|}{ Wanted to get pregnant } \\
\hline Wanted to get pregnant & 37.9 & 26.8 & 35.2 & \\
\hline Wanted to wait longer & 52.0 & 27.1 & 20.9 & \\
\hline Did not want to get pregnant & 47.0 & 33.1 & 19.9 & $<0.001$ \\
\hline \multicolumn{5}{|l|}{ Feelings towards pregnancy } \\
\hline Satisfied & 50.5 & 23.1 & 26.4 & \\
\hline More or less satisfied & 47.0 & 30.7 & 22.3 & \\
\hline Dissatisfied & 35.3 & 48.3 & 16.4 & $<0.001$ \\
\hline \multicolumn{5}{|l|}{ Tried to terminate the pregnancy } \\
\hline No & 48.1 & 28.6 & 23.2 & \\
\hline Yes & 20.5 & 56.5 & 22.9 & $<0.001$ \\
\hline Total (national sample) & 46.6 & 30.1 & 23.2 & \\
\hline
\end{tabular}

* Values are weighted according to sample design. 
Table 4

Percentage of women receiving and presenting hand-held prenatal notes to record the results of exams and implementation of educational practices during prenatal care per region in a national sample of postpartum women. Brazil, 2011-2012 *.

\begin{tabular}{|c|c|c|c|c|c|c|c|}
\hline \multirow[t]{2}{*}{ Variables } & \multirow[b]{2}{*}{ North } & \multicolumn{3}{|c|}{ Region } & \multirow[b]{2}{*}{ Central } & \multirow[t]{2}{*}{ p-value } & \multirow{2}{*}{$\begin{array}{c}\text { Total (nationa } \\
\text { sample) }\end{array}$} \\
\hline & & Northeast & Southeast & South & & & \\
\hline \multicolumn{8}{|c|}{ Has hand-held prenatal notes } \\
\hline No & 2.1 & 5.1 & 3.7 & 2.9 & 5.8 & & 4.0 \\
\hline Yes & 97.9 & 94.9 & 96.3 & 97.1 & 94.2 & 0.130 & 96.0 \\
\hline \multicolumn{8}{|c|}{ Presented hand-held prenatal notes } \\
\hline No & 35.6 & 31.6 & 21.8 & 20.0 & 54.8 & & 27.9 \\
\hline Yes & 64.4 & 68.4 & 78.2 & 80.0 & 45.2 & $<0.001$ & 72.1 \\
\hline \multicolumn{8}{|c|}{ Record of result of 1st blood glucose } \\
\hline No record & 21.8 & 22.7 & 16.0 & 10.9 & 16.5 & & 17.6 \\
\hline Recorded & 78.2 & 77.3 & 84.0 & 89.1 & 83.5 & $<0.001$ & 82.4 \\
\hline \multicolumn{8}{|c|}{ Record of result of 2 nd blood glucose } \\
\hline No record & 67.4 & 71.5 & 58.4 & 44.2 & 61.1 & & 60.0 \\
\hline Recorded & 32.6 & 28.5 & 41.6 & 55.8 & 38.9 & $<0.001$ & 39.2 \\
\hline \multicolumn{8}{|c|}{ Record of results of urinalysis } \\
\hline No record & 21.7 & 17.2 & 13.6 & 7.6 & 14.9 & & 14.5 \\
\hline Recorded & 78.3 & 82.8 & 86.4 & 92.4 & 85.1 & $<0.001$ & 85.5 \\
\hline \multicolumn{8}{|c|}{ Record of results of ultrasonography scan } \\
\hline No record & 55.3 & 43.2 & 28.5 & 26.9 & 60.3 & & 37.2 \\
\hline Recorded $<14$ weeks & 12.3 & 17.6 & 33.3 & 35.2 & 18.0 & & 26.0 \\
\hline Recorded $\geq 14$ weeks & 32.4 & 39.2 & 38.1 & 37.8 & 21.7 & $<0.001$ & 36.8 \\
\hline \multicolumn{8}{|c|}{ Performing ultrasonography scan } \\
\hline No & 7.0 & 2.1 & 0.6 & 1.3 & 1.5 & & 1.8 \\
\hline Yes & 93.0 & 97.9 & 99.4 & 98.7 & 98.5 & $<0.001$ & 98.2 \\
\hline \multicolumn{8}{|l|}{ Received information on: } \\
\hline \multicolumn{8}{|l|}{ Onset of labour } \\
\hline No & 53.5 & 49.1 & 51.5 & 42.5 & 46.1 & & 49.5 \\
\hline Yes & 46.5 & 50.9 & 48.5 & 57.5 & 53.9 & 0.002 & 50.5 \\
\hline \multicolumn{8}{|c|}{ Signs of risk during pregnancy } \\
\hline No & 43.2 & 39.0 & 38.6 & 28.9 & 36.5 & & 37.8 \\
\hline Yes & 56.8 & 61.0 & 61.4 & 71.1 & 63.5 & $<0.001$ & 62.2 \\
\hline \multicolumn{8}{|c|}{ Activities to facilitate childbirth } \\
\hline No & 60.5 & 56.9 & 61.3 & 57.0 & 53.2 & & 58.9 \\
\hline Yes & 39.5 & 43.1 & 38.7 & 43.0 & 46.8 & 0.020 & 41.1 \\
\hline \multicolumn{8}{|c|}{ Breastfeeding in the 1 st hour of life } \\
\hline No & 34.1 & 29.4 & 42.1 & 34.7 & 30.9 & & 36.0 \\
\hline Yes & 65.9 & 70.6 & 57.9 & 65.3 & 69.1 & $<0.001$ & 64.0 \\
\hline
\end{tabular}

*Values are weighted according to sample design.

Prenatal visits were held primarily in primary health care units (89.6\%). A greater proportion of prenatal care visits held in hospitals were observed in women of older age and of higher level of education, and with previous unfavourable pregnancy outcome.

As for the professional cadre who conducted most prenatal consultations, $75.6 \%$ of pregnant women were seen by a medical professional, and we can notice the existence of a gradient according to age and education: the higher the age of the woman and her schooling, greater the proportion of care by physicians. In contrast, in the North and Northeast regions, half of the women had prenatal care consultation provided by non-medical professional. Women with three or more previous pregnancies and adverse pregnancy outcomes were seen to a greater extent by 
Proportional distribution of mothers' characteristics according to the source of payment and the profile of care provided in most prenatal visits on a national sample of postpartum women. Brazil, 2011-2012 *.

\begin{tabular}{|c|c|c|c|c|c|c|c|c|c|c|c|}
\hline \multirow[t]{2}{*}{ Exposure/Outcome } & \multicolumn{2}{|c|}{ Source of financing } & \multirow[t]{2}{*}{$\mathrm{p}$-value } & \multicolumn{2}{|c|}{$\begin{array}{c}\text { Type of health } \\
\text { facility }\end{array}$} & \multirow[t]{2}{*}{ p-value } & \multicolumn{2}{|c|}{ Professional cadre } & \multirow[t]{2}{*}{ p-value } & \multirow{2}{*}{$\begin{array}{c}\text { Continuity } \\
\text { of pro- } \\
\text { vider }\end{array}$} & \multirow{2}{*}{ p-value } \\
\hline & Public & Private & & $\begin{array}{c}\text { Primary } \\
\text { care }\end{array}$ & $\begin{array}{c}\text { Hospital } \\
\text { outpatient }\end{array}$ & & Physician & $\begin{array}{c}\text { Nurse } \\
\text { Midwife }\end{array}$ & & & \\
\hline \multicolumn{12}{|l|}{ Region } \\
\hline North & 88.1 & 11.9 & & 93.3 & 6.7 & & 49.6 & 50.4 & & 86.3 & \\
\hline Northeast & 78.0 & 22.0 & & 87.2 & 12.8 & & 48.4 & 51.6 & & 91.1 & \\
\hline Southeast & 71.5 & 28.5 & & 90.1 & 9.9 & & 91.9 & 8.1 & & 88.4 & \\
\hline South & 67.4 & 32.6 & & 89.5 & 10.5 & & 95.2 & 4.8 & & 86.4 & \\
\hline Central & 74.9 & 25.1 & $<0.001$ & 90.8 & 9.2 & 0.104 & 89.4 & 10.6 & $<0.001$ & 82.9 & 0.003 \\
\hline \multicolumn{12}{|l|}{ Age (years) } \\
\hline $10-14$ & 94.9 & 5.1 & & 91.3 & 8,7 & & 58.2 & 41.8 & & 91.0 & \\
\hline $15-19$ & 92.1 & 7.9 & & 91.0 & 9.0 & & 64.1 & 35.9 & & 86.5 & \\
\hline $20-34$ & 72.3 & 27.7 & & 89.8 & 10.2 & & 77.5 & 22.5 & & 88.6 & \\
\hline 35 or more & 58.6 & 41.4 & $<0.001$ & 83.4 & 16.6 & $<0.001$ & 83.9 & 16.1 & $<0.001$ & 89.8 & 0.007 \\
\hline \multicolumn{12}{|l|}{ Race/Ethnicity/Skin colour } \\
\hline White & 61.3 & 38.7 & & 89.6 & 10.4 & & 86.6 & 13.4 & & 89.1 & \\
\hline Black & 89.3 & 10.7 & & 88.6 & 11.4 & & 70.3 & 29.7 & & 86.4 & \\
\hline Brown & 80.4 & 19.6 & & 89.8 & 10.2 & & 69.7 & 30.3 & & 88.3 & \\
\hline Yellow (Asian) & 72.6 & 27.4 & & 84.0 & 16.0 & & 76.4 & 23.6 & & 89.6 & \\
\hline Indigenous & 86.0 & 14.0 & $<0.001$ & 87.5 & 12.5 & 0.446 & 64.4 & 35.6 & $<0.001$ & 81.9 & 0.094 \\
\hline \multicolumn{12}{|l|}{ Mother's level of education } \\
\hline Incomplete Primary School & 94.8 & 5.2 & & 91.7 & 8.3 & & 59.9 & 40.1 & & 86.3 & \\
\hline Complete Primary School & 88.6 & 11.4 & & 89.9 & 10.1 & & 73.6 & 26.4 & & 86.9 & \\
\hline Complete Secondary school & 65.2 & 34.8 & & 87.7 & 12.3 & & 82.5 & 17.5 & & 89.4 & \\
\hline University and further & 18.4 & 81.6 & $<0.001$ & 83.1 & 16.9 & $<0.001$ & 96.4 & 3.6 & $<0.001$ & 94.2 & $<0.001$ \\
\hline \multicolumn{12}{|l|}{ Conjugal status } \\
\hline Without partner & 83.7 & 16.3 & & 89.7 & 10.3 & & 73.4 & 26.6 & & 87.8 & \\
\hline With partner & 72.6 & 27.4 & $<0.001$ & 89.5 & 10.5 & 0.829 & 76.1 & 23.9 & 0.017 & 88.5 & 0.386 \\
\hline \multicolumn{12}{|l|}{ Previous pregnancies } \\
\hline None & 70.5 & 29.5 & & 89.9 & 10.1 & & 76.3 & 23.7 & & 89.1 & \\
\hline 1 & 71.1 & 28.9 & & 90.1 & 9.9 & & 77.9 & 22.1 & & 88.7 & \\
\hline 2 & 79.3 & 20.7 & & 89.9 & 10.1 & & 75.3 & 24.7 & & 88.1 & \\
\hline 3 or more & 88.3 & 11.7 & $<0.001$ & 87.7 & 12.3 & 0.076 & 69.4 & 30.6 & $<0.001$ & 86.0 & 0.014 \\
\hline \multicolumn{12}{|l|}{ Previous negative outcomes } \\
\hline No & 76.3 & 23.7 & & 90.4 & 9.6 & & 76.1 & 23.9 & & 88.1 & \\
\hline Yes & 80.9 & 19.1 & $<0.001$ & 86.8 & 13.2 & $<0.001$ & 72.5 & 27.5 & 0.006 & 87.3 & 0.433 \\
\hline Total (national sample) & 74.6 & 25.4 & & 89.6 & 10.4 & & 75.6 & 24.4 & & 88.4 & \\
\hline
\end{tabular}

* Values are weighted according to sample design.

nurses and midwives, compared to those with fewer pregnancies and without adverse outcomes (Table 5).

Analyzing the continuity of provider in prenatal care, it was found that $11.6 \%$ of women reported having not been accompanied by the same professional throughout gestation. Again, a gradient in relation to schooling could be noticed: women with higher educational level had greater proportion of care provided by the same professional. Adolescents aged 10 to 14 years, women with fewer pregnancies and residents in the Northeast region also showed higher proportion of attendance by the same health professional. Although we found no significant difference, it is noteworthy that the same professional did not 
accompany almost a fifth of indigenous women during pregnancy (Table 5).

Table 6 presents the associated risks during the prenatal and delivery and the factors relating to network for care in the country. A quarter of the postpartum women interviewed said that their pregnancy was classified as "at risk", especially those belonging to the extreme age (adolescents under 15 years old and women aged 35 or more years of age) with 3 or more previous pregnancies, and those with previous unfavourable outcome. When a woman needs more complex care in a referral service, although the majority of pregnant women considered at risk reported that they achieved that level of care, $11.5 \%$ said they achieved this care with difficulty.

Approximately $60 \%$ of women were advised on maternity referral to hospital for delivery. Women living in the North and Northeast regions, adolescents, especially those with 10-14 years of age, and women of lower educational level were the ones that least reported receiving this advice, while white primiparous women were the main recipients of this care (Table 6). Of those receiving guidance, $84.5 \%$ had their delivery attended in the maternity hospital indicated. Women residing in the Southern region, with higher level of education, older age, living with partner and with more pregnancies were the one who most gave birth in the maternity indicated, this value being almost $100 \%$ among indigenous women.

Before getting to the hospital where the delivery was attended, $16.2 \%$ of women sought care at another hospital (Table 6). Most of these women sought only one service, but $15 \%$ reported having sought two to six health units before getting admission. The main reasons cited were lack of health service conditions (40\%), lack of doctors, lack of supplies and equipment, there was no vacancy for the mother and/or the baby (29.5\%) and clinical risk and/or obstetric risk (19.4\%). Other issues such as the health care unit does not provide delivery care $(3 \%)$, poor quality of care, including reports of abuse and mistreatment $(2.7 \%)$, the health care unit profile sought, with restrictions of the health service according to the characteristics of the pregnant woman, as for example, a pregnant adolescent or primiparous women (4\%) were also mentioned but less frequently (data not shown in table). In Table 6, data shows that the pilgrimage of women at admission for delivery was more frequent among residents in the Northeast region of the country, of brown, black or yellow race/ethnicity or skin colour, in adolescents, women with lower level of education, those without a partner; and those who were in their first pregnancy.

\section{Discussion}

The results of this study show that the coverage of prenatal care in Brazil is almost universal, with high attendance in all regions of the country and in women of different demographic, social and reproductive characteristics. However, the appropriateness of such care is still low: $75.8 \%$ of women began prenatal care before the 16 th gestational week and only $73.1 \%$ had the minimum number of visits for gestational age at delivery, results also observed in other national studies 5,6,9,10,16,17. Using the current recommendation of the Stork Network programme of the Ministry of Health 18, also adopted in other countries 19,20 , that the initiation prenatal visists is performed until the $12^{\text {th }}$ gestational week, early booking is reduced to $60.6 \%$. When other parameters are included, such as carrying out routine prenatal tests and information about delivery and breastfeeding, it was found that less than $10 \%$ of women received the recommended procedures (data not shown in table), similar to that found in other studies adopting similar evaluation parameters 5,6,9.

Several barriers for not attending prenatal care or early booking were identified, highlighting the social inequalities that persist in the country, with less access to indigenous and black women 21 , those with less education $4,7,11$, with higher number of pregnancies 4,7,22, and residents in the North and Northeast region 11,23.

The high proportion of postpartum women who justified not having initiated prenatal care early for not knowing they were pregnant indicates difficulties in the diagnosis of pregnancy and the need to facilitate women's access to diagnostic methods, preferably immediate results, allowing faster uptake of pregnant women for prenatal care.

More than half of the women interviewed did not want to get pregnant at that time and a third showed negative or ambivalent feelings towards the current pregnancy. About $2.3 \%$ of respondents, representing more than 50,000 women in the expanded sample, said they had tried to interrupt the current pregnancy. These women with unwanted pregnancies, and women without a partner had lower prenatal care coverage and late booking of care, a fact already reported by Bassani et al. 24 in their study. Among the reasons given, we highlight the high proportion of personal problems as justification for these results, indicating that improving prenatal care depends on other actions, such as the expansion of family planning.

Pregnant adolescents, especially the very young 25 , under 15 years old also demonstrated 
Proportional distribution of mothers' characteristics according to pregnancy risk and delivery care network in a national sample of postpartum women. Brazil 2011-2012 *.

\begin{tabular}{|c|c|c|c|c|c|c|c|c|c|c|c|c|}
\hline \multirow[t]{2}{*}{ Exposure/Outcome } & \multirow[t]{2}{*}{$\begin{array}{c}\text { Pregnancy } \\
\text { risk }\end{array}$} & \multirow[t]{2}{*}{$\begin{array}{c}\mathrm{p}- \\
\text { value }\end{array}$} & \multicolumn{3}{|c|}{$\begin{array}{l}\text { Attended in the } \\
\text { referred hospital }\end{array}$} & \multirow[t]{2}{*}{$\begin{array}{c}\mathrm{p}- \\
\text { value }\end{array}$} & \multirow{2}{*}{$\begin{array}{l}\text { Guidance } \\
\qquad \text { on } \\
\text { maternity } \\
\text { reference }\end{array}$} & \multirow[t]{2}{*}{$\begin{array}{c}\mathrm{p}- \\
\text { value }\end{array}$} & \multirow{2}{*}{$\begin{array}{l}\text { Delivery } \\
\text { in } \\
\text { maternity } \\
\text { indicated }\end{array}$} & \multirow{2}{*}{$\begin{array}{c}\mathrm{p}- \\
\text { value }\end{array}$} & \multirow{2}{*}{$\begin{array}{c}\text { Pilgrimage } \\
\text { for } \\
\text { childbirth }\end{array}$} & \multirow{2}{*}{$\begin{array}{c}\mathrm{p}- \\
\text { value }\end{array}$} \\
\hline & & & No & $\begin{array}{r}\text { Yes, } \\
\text { with diffic }\end{array}$ & $\begin{array}{l}\text { Yes, } \\
\text { without } \\
\text { difficulty }\end{array}$ & & & & & & & \\
\hline \multicolumn{13}{|l|}{ Region } \\
\hline North & 22.3 & & 10.6 & 9.7 & 79.8 & & 49.4 & & 86.9 & & 16.9 & \\
\hline Northeast & 25.0 & & 7.9 & 14.4 & 77.7 & & 54.7 & & 80.8 & & 25.1 & \\
\hline Southeast & 24.6 & & 10,1 & 10.3 & 79.6 & & 61.8 & & 83.7 & & 12.8 & \\
\hline South & 25.4 & & 6.3 & 8.1 & 85.7 & & 64.0 & & 92.3 & & 6.5 & \\
\hline Central & 22.5 & 0.820 & 10.8 & 17.9 & 71.2 & 0.275 & 59.7 & 0.001 & 86.0 & $<0.001$ & 16.5 & $<0.001$ \\
\hline \multicolumn{13}{|l|}{ Age (years) } \\
\hline $10-14$ & 42.6 & & 6.8 & 10.1 & 83.0 & & 48.1 & & 78.9 & & 21.2 & \\
\hline $15-19$ & 20.4 & & 9.4 & 12.4 & 78.2 & & 52.5 & & 82.2 & & 21.3 & \\
\hline $20-34$ & 22.9 & & 9.6 & 11.3 & 79.1 & & 60.0 & & 84.5 & & 15.4 & \\
\hline 35 or more & 39.1 & $<0.001$ & 6.9 & 12.1 & 81.0 & 0.931 & 61.9 & $<0.001$ & 87.9 & 0.005 & 12.5 & $<0.001$ \\
\hline \multicolumn{13}{|l|}{ Race/Ethnicity/Skin colour } \\
\hline White & 24.7 & & 10.9 & 12.9 & 76.2 & & 62.7 & & 87.6 & & 12.2 & \\
\hline Black & 27.0 & & 9.0 & 10.2 & 80.8 & & 55.5 & & 79.6 & & 19.6 & \\
\hline Brown & 23.8 & & 8.2 & 11.1 & 80.7 & & 56.9 & & 83.2 & & 18.1 & \\
\hline Yellow (Asian) & 29.0 & & 2.8 & 39.0 & 93.4 & & 57.8 & & 77.4 & & 19.8 & \\
\hline Indigenous & 28.9 & 0.268 & - & 24.3 & 75.7 & 0.537 & 53.8 & $<0.001$ & 98.1 & $<0.001$ & 9.4 & $<0.001$ \\
\hline \multicolumn{13}{|l|}{ Mother's level of education } \\
\hline Incomplete Primary School & 25.9 & & 12.9 & 10.3 & 76.8 & & 52.1 & & 82.5 & & 20.7 & \\
\hline Complete Primary School & 23.8 & & 6.4 & 10.3 & 83.3 & & 56.3 & & 81.9 & & 18.5 & \\
\hline Secondary School Complete & 24.1 & & 8.7 & 12.7 & 78.6 & & 62.2 & & 84.6 & & 14.0 & \\
\hline University and further & 23.5 & 0.368 & 4.2 & 15.5 & 80.4 & 0.128 & 70.8 & $<0.001$ & 94.2 & $<0.001$ & 5.9 & $<0.001$ \\
\hline \multicolumn{13}{|l|}{ Conjugal status } \\
\hline Without partner & 24.4 & & 13.4 & 13.0 & 73.7 & & 56.7 & & 80.7 & & 18.1 & \\
\hline With partner & 24.5 & 0.938 & 8.1 & 11.2 & 80.8 & 0.164 & 59.2 & 0.078 & 85.3 & 0.001 & 15.8 & 0.042 \\
\hline \multicolumn{13}{|l|}{ Previous pregnancies } \\
\hline None & 19.8 & & 8.1 & 12.9 & 79.1 & & 59.8 & & 83.8 & & 17.6 & \\
\hline 1 & 22.8 & & 10.4 & 10.0 & 79.6 & & 59.1 & & 83.7 & & 15.1 & \\
\hline 2 & 28.1 & & 8.6 & 13.3 & 78.1 & & 57.5 & & 87.5 & & 14.6 & \\
\hline 3 or more & 36.0 & $<0.001$ & 9.2 & 10.1 & 80.8 & 0.826 & 56.2 & 0.036 & 85.1 & 0.030 & 16.1 & 0.012 \\
\hline \multicolumn{13}{|l|}{ Previous negative outcomes } \\
\hline No & 22.1 & & 8.7 & 10.1 & 81.2 & & 57.5 & & 85.7 & & 14.8 & \\
\hline Yes & 40.5 & $<0.001$ & 10.4 & 11.7 & 77.8 & 0.607 & 58.9 & 0.305 & 83.4 & 0.070 & 16.3 & 0.121 \\
\hline Total (national sample) & 24.4 & & 9.0 & 11.5 & 79.5 & & 58.7 & & 84.5 & & 16.2 & \\
\hline
\end{tabular}

* Values are weighted according to sample design.

a delayed booking of care and fewer visits, results also observed in other studies 22 , demonstrating the importance of differentiated strategies for this age group. Prenatal care itself should be viewed with an opportunity guidance to prevent a recurrent unplanned pregnancy in adolescents 26 .
Women with greater reproductive risk, with negative outcomes in previous pregnancies had lower prenatal coverage, late booking and had fewer prenatal care visits than women without a history of obstetric risk. Unaware that she was pregnant was a reported more often by these women, when compared to those with no repro- 
ductive risk, indicating problems in the diagnosis of pregnancy and the uptake of prenatal care services. Similar results were observed in other national studies 7,28 and reinforce the need for services to have mechanisms to identify those women who are the ones who would benefit most from early and appropriate monitoring.

The proportion of women who received hand-held prenatal notes during their prenatal care was high and similar to that found in the PNDS 2006 11. However, the proportion of women who had hand-held prenatal notes on admission for delivery was less than that observed in other studies nationwide 29 and is probably due to the inclusion of private services in this study, as were women with greater education showed less hand-held prenatal notes (data not shown in table).

Despite the results of the first line routine tests being recorded is high, it failed to reach $100 \%$ in all of the regions of the country, similar to that found in PNDS 2006 11, with the filling of the second line exams very low, less than $40 \%$ and only the region South having a slightly better performance $(55.8 \%)$. It is emphasized that the main goal of prenatal care routine tests is to identify complications in pregnancy with timely interventions to preserve the health of the woman and the fetus, and the prenatal care notes is one of the main instruments of communication between teams of prenatal care and delivery care, regarding the complications identified and procedures adopted. The lowest proportion of results of the ultrasonography scan recorded on the hand-held prenatal care notes, in relation to that referred by the women, suggests problems in recording these results, which are possibly common to recording other prenatal test results. Despite the high coverage of ultrasonography scan, a very small proportion of exams were performed before the $14^{\text {th }}$ week of pregnancy, when this test has greater accuracy in the calculation of gestational age, essential for monitoring the progress of the pregnancy and any related decisions for interruption of pregnancy 19.

The low proportion of information received during prenatal care highlights the role of inadequate prenatal care in preparing women for childbirth and breastfeeding. Guidance on practices to facilitate the delivery are of importance for the promotion of normal birth had the lowest frequency, mostly prioritized the guidance on identification of signs of risk, strengthening the biomedical nature of care.

As to the organization of prenatal care, it appears that it occurs primarily in public health services and primary care units, with only $10.4 \%$ of women cared for in outpatient hospital units.-
Prenatal care provided by nurses and midwives is restricted in the country, with the highest concentration in the North and Northeast and among indigenous women, probably due to lower availability of doctors in these regions, especially in the inner cities. According to the Law Decree no. 94406/87 30 about the Law of Professional Nursing Practice, prenatal care for low-risk pregnancies can be fully provided by nurses 3 . Moreover, one of the guidelines for prenatal care established by National Policy for the Humanization of Prenatal and Birth Care (PHPN) 12 and the Stork Network (Rede Cegonha) 18 is the participation of the nurse midwife as a member of the healthcare team who provides direct care to women during pregnancy, labour and birth.

Almost $90 \%$ of the postpartum women reported that they had been cared by the same health professional during prenatal care, indicating the continuity of provider is fundamental to the development of bonding and trust between the professional and the pregnant woman and the best monitoring of pregnancy. The fragmentation of care with consultations by different professionals has been associated with poor prenatal care quality ${ }^{31}$. In the present study, we noted that among women with higher education, doctors provided prenatal care almost exclusively in private health care services with the same health care professional monitoring throughout pregnancy, reflecting the pattern of organization in this sector.

The relationship of prenatal care with other health care services network indicated problems - no provision of care, or care with difficulty - a fifth of pregnant women at risk being referred to health services. Although statistically significant difference was not found, it is noteworthy that women with a poor obstetric history with a greater risk for new unfavorable outcomes were those that reported more difficulties in acessing the health care services. These women also had their prenatal care provided in greater proportion by nurses and midwives, revealing problems in the organization of care. These are the women who would most benefit from specialized care by physicians, revealing problems of the service network to ensure the most appropriate level of care according to the needs of women.

Another failure was observed in the interaction between prenatal care services and childbirth care services. There were a low proportion of women receiving guidance on maternity reference hospital for delivery, reported by less than $60 \%$ of informants. The pilgrimage for childbirth care was high, higher than that found in the PNDS 200611 , being mainly observed in residents in the Northeast, in women with lower educational lev- 
el and adolescents, who were also the least likely to receive guidance about hospital reference and fewer were admitted in the indicated health service. The findings in this study reflects a deficiency in the hospital referral system for care during birth, causing risks to women's and baby's health. According to Menezes et al. 8, the situation becomes even more serious when considering that most women who wandered seeking hospital care at another hospital by their own means. In their study conducted in the city of Rio de Janeiro, only one fifth of the women were transported by ambulance.

The results of this study relate to women having a hospital birth, in health care units with more than 500 deliveries per year, representing nearly $80 \%$ of women in the country. It is likely that the results of prenatal care for women having their delivery at home or in transit, as well as those occurring in hospitals with lower volume of hospitalizations, exhibit characteristics different from those presented, and expected an even more limited access to adequate care.

\section{Conclusion}

As a conclusion, we can say that Brazil was successful in expanding access to prenatal care, reaching almost all of Brazilian women. Challenges remain, however, for improving the quality of such care with the completion of all procedures considered effective for reducing unfavourable outcomes. Reducing maternal mortality and the high rate of caesarean section, the prevention of injuries and preventable deaths, will not be achieved without overcoming the barriers to early diagnosis of pregnancy, early prenatal care booking in the first weeks of pregnancy, especially for pregnant women with greater reproductive risk, and use of contacts with health care services for the provision of effective care such as diagnosis and treatment of diseases and the promotion of health.

The integration of prenatal care with other health care services in the health care network through the establishment of an integrated network of reference and counter-reference with guaranteed inpatient beds by means of a central regulation of vacancies is essential for timely care to pregnant women at risk who were at increased risk of negative outcomes.

Although the linkage of pregnant women to the maternity of reference for childbirth care is regulated since 2007 (Law no. 11,634 of December 27, 200732 ), and is a recommendation of the Stork Network 18 for the integration of prenatal care services and delivery care, targeting the reception of pregnant women and ensuring hospital beds for hospitalization, improvements are needed in order to prevent the pilgrimage for childbirth of the women and families, still common in many parts of the country. 


\section{Resumen}

El estudio tiene por objetivo describir el cuidado prenatal ofrecido a las embarazadas por parte de los servicios de salud públicos o privados en Brasil, utilizando los datos de la encuesta Nacer en Brasil, realizada en 2011 y 2012. La información se obtuvo mediante entrevistas con las mujeres después del parto, durante la hospitalización, y la ficha prenatal. Los resultados indican una alta cobertura (98,7\%), con un 75,8\% de las mujeres que comenzaron la atención prenatal antes de las 16 semanas de gestación y un 73,1\% que tuvieron seis o más consultas. La atención prenatal se llevó a cabo en las unidades básicas de atención (89,6\%), públicas $(74,6 \%)$, por un mismo profesional $(88,4 \%)$, la mayoría médicos $(75,6 \%)$ y el $96 \%$ recibió una ficha prenatal. Una cuarta parte de las mujeres se consideraba en riesgo. Del total, sólo el 58,7\% estaban orientadas sobre la unidad de maternidad de referencia, y el 16,2\% dice que han buscado más de un servicio para el parto. Sigue habiendo problemas para mejorar la calidad de la atención, y es necesaria la realización de procedimientos efectivos para reducir los resultados desfavorables.

Atención Prénatal; Salud Materno-Infantil; Servicios de Salud Materno-Intantil

\section{Contributors}

E. F. Viellas, R. M. S. M. Domingues, and M. C. Leal participated in the design of the article, all stages of production and were responsible for the final version. $\mathrm{M}$. A. B. Dias, S. G. N. Gama, M. M. Theme Filha, J. V. Costa and M. H. Bastos participated in the critical revision and approval of the final version.

\section{Acknowledgements}

To regional and state coordinators, supervisors, interviewers and crew of the study and the mothers who participated and made this study possible. To Graduate Studies Coordinating Board for their support on the Postdoctoral Program in the State of Rio de Janeiro.

\section{Funding}

National Council for Scientific and Technological Development (CNPq); Science and Tecnology Department, Secretariat of Science, Tecnology, and Strategic Inputs, Brazilian Ministry of Health; National School of Public Health, Oswaldo Cruz Foundation (INOVA Project); and Foundation for supporting Research in the State of Rio de Janeiro (Faperj).

\section{References}

1. Carroli G, Rooney C, Villar J. How effective is antenatal care in preventing maternal mortality and serious morbidity? An overview of the evidence. Paediatr Perinat Epidemiol. 2001; 15 Suppl 1:1-42.

2. Barros FC, Bhutta ZA, Batra M, Hansen TN, Victora CG, Rubens CE. Global report on preterm and stillbirth (3 of 7): evidence for effectiveness of interventions. BMC Pregnancy Childbirth 2010; 10 Suppl 1:S3.

3. Ministério da Saúde. Pré-natal e puerpério: atenção qualificada e humanizada. Manual Técnico. Brasília: Ministério da Saúde; 2006. (Série A. Normas e Manuais Técnicos; Série Direitos Sexuais e Direitos Reprodutivos - Caderno 5).

4. Coimbra LC, Silva AAM, Mochel EG, Alves MTSSB, Ribeiro VS, Aragão VMF, et al. Fatores associados à inadequação do uso da assistência pré-natal. Rev Saúde Pública 2003; 37:456-62.

5. Coutinho T, Monteiro MFG, Sayd JD, Teixeira MTB, Coutinho CM, Coutinho LM. Monitoring the prenatal care process among users of the Unified Health Care System in a city of the Brazilian Southeast. Rev Bras Ginecol Obstet 2010; 32:563-9.
6. Domingues RMSM, Hartz ZMA, Dias MAB, Leal MC. Avaliação da adequação da assistência prénatal na rede SUS do Município do Rio de Janeiro, Brasil. Cad Saúde Pública 2012; 28:425-37.

7. Leal MC, Gama SGN, Campos MR, Cavalini LT, Garbayo LS, Brasil CLP, et al. Fatores associados à morbi-mortalidade perinatal em uma amostra de maternidades públicas e privadas do Município do Rio de Janeiro, 1999-2001. Cad Saúde Pública 2004; 20 Supp 1:20-33.

8. Menezes DCS, Leite IC, Schramm JMA, Leal MC. Avaliação da peregrinação anteparto numa amostra de puérperas no Município do Rio de Janeiro, Brasil, 1999/2001. Cad Saúde Pública 2006; 22:553-9.

9. Andreucci CB, Cecatti JG. Desempenho de indicadores de processo do Programa de Humanização do Pré-Natal e Nascimento no Brasil: uma revisão sistemática. Cad Saúde Pública 2011; 27:1053-64.

10. Serruya SJ, Cecatti JG, Lago TG. O Programa de Humanização no Pré-natal e Nascimento do Ministério da Saúde no Brasil: resultados iniciais. Cad Saúde Pública 2004; 20:1281-9. 
11. Ministério da Saúde. Pesquisa Nacional de Demografia e Saúde da Criança e da Mulher - PNDS 2006: dimensões do processo reprodutivo e da saúde da criança. Brasília: Ministério da Saúde; 2009.

12. Secretaria de Políticas de Saúde Ministério da Saúde. Programa de Humanização no Pré-Natal e Nascimento. Brasília: Ministério da Saúde; 2002.

13. Vasconcellos MTL, Silva PLN, Pereira APE, Schilithz AOC, Souza Junior PRB, Szwarcwald CL. Desenho da amostra Nascer no Brasil: Pesquisa Nacional sobre Parto e Nascimento. Cad Saúde Pública 2014; 30 Suppl:S49-58.

14. do Carmo Leal M, da Silva AA, Dias MA, da Gama SG, Rattner D, Moreira ME, et al. Birth in Brazil: national survey into labour and birth. Reprod Health 2012; 9:15

15. Santos Neto ET, Leal MC, Oliveira AE, Zendonade E, Gama SGN. Concordância entre informações do cartão da gestante e da memória materna sobre assistência pré-natal. Cad Saúde Pública 2012; 28:256-66.

16. Ribeiro ERO, Guimarães AMDN, Bettiol H, Lima DDF, Almeida ML, Souza L, et al. Risk factors for inadequate prenatal care use in the metropolitan area of Aracaju, Northeast Brazil. BMC Pregnancy Childbirth 2009; 9:31.

17. Carvalho DS, Novaes HMD. Avaliação da implantação de programa de atenção pré-natal no município de Curitiba, Paraná, Brasil: estudo em coorte de primigestas. Cad Saúde Pública 2004; 20 Suppl 2:S220-30.

18. Ministério da Saúde. Portaria consolidada Rede Cegonha. http://portal.saude.gov.br/portal/arqui vos/pdf/portaria_consolidada_cegonha.pdf (accessed on 24/Jun/2013).

19. National Institute for Health and Clinical Excellence. Antenatal care: routine care for the healthy pregnant woman. Clinical guideline march 2008. http://www.nice.org.uk/nicemedia/ live/11947/40145/40145.pdf (accessed on 12/Aug/ 2010).

20. American College of Obstetricians and Gynecologists. Standards for obstetric-gynecologic services. Washington DC: American College of Obstetricians and Gynecologists; 1985.

21. Leal MC, Gama SGN, Cunha CB. Desigualdades raciais, sociodemográficas e na assistência ao prénatal e ao parto, 1999-2001. Rev Saúde Pública 2005; 39:100-17.

22. Gama SGN, Szwarcwald CL, Sabroza AR, Branco VC, Leal MC. Fatores associados à assistência prénatal precária em uma amostra de puérperas adolescentes em maternidades do Município do Rio de Janeiro, 1999-2000. Cad Saúde Pública 2004; 20 Suppl 1:S101-11.
23. Victora CG, Aquino EML, Leal MC, Monteiro CA, Barros FC, Szwarcwald CL. Maternal and child health in Brazil: progress and challenges. Lancet 2011; 377:1863-76.

24. Bassani DG, Surkan PJ, Olinto MTA. Inadequate use of prenatal services among Brazilian women: the role of maternal characteristics. Int Perspect Sex Reprod Health 2009; 35:15-20

25. Hueston WJ, Geesey ME, Diaz V. Prenatal care initiation among pregnant teens in the United States: an analysis over 25 years. J Adolesc Health 2008; 48:243-8.

26. Viellas EF, Gama SGN, Theme Filha MM, Leal MC. Gravidez recorrente na adolescência e os desfechos negativos no recém-nascido: um estudo no Município do Rio de Janeiro. Rev Bras Epidemiol 2012; 15:443-54.

27. Leal MC, Gama SGN, Ratto KMN, Cunha CB. Uso do índice de Kotelchuck modificado na avaliação da assistência pré-natal e sua relação com as características maternas e o peso do recém-nascido no Município do Rio de Janeiro. Cad Saúde Pública 2004; 20 Suppl 1:S63-72.

28. Domingues RMSM. Avaliação da implantação da assistência pré-natal na rede SUS do Município do Rio de Janeiro com ênfase nas ações de controle da sífilis e do HIV [Doctoral Dissertation]. Rio de Janeiro: Escola Nacional de Saúde Pública Sérgio Arouca; Fundação Oswaldo Cruz; 2011.

29. Szwarcwald CL, Barbosa Junior A, Miranda AE, Paz LC. Resultados do estudo Sentinela-parturiente, 2006: desafios para o controle da sífilis congênita no Brasil. DST J Bras Doenças Sex Transm 2007; 19(3-4):128-33.

30. Brasil. Decreto no 94.406 de 8 de junho de 1987. Regulamenta a Lei no 7.498, de 25 de junho de 1986, que dispõe sobre o exercício da Enfermagem, e dá outras providências. Diário Oficial da União 1987; 9 jun.

31. Petrou S, Kupek E, Vause S, Maresh M. Clinical, provider and sociodemographic determinants of the number of antenatal visits in England and Wales. Soc Sci Med 2001; 52:1123-34.

32. Brasil. Lei $\mathrm{n}^{\mathrm{o}}$. 11.634 de 27 de dezembro de 2007. Dispõe sobre o direito da gestante ao conhecimento e a vinculação à maternidade onde receberá assistência no âmbito do SUS. Diário Oficial da União 2007; $28 \mathrm{dez}$.

Submitted on $05 / \mathrm{Jul} / 2013$

Final version resubmitted on $05 / \mathrm{Dec} / 2013$

Approved on 13/Dec/2013 